\title{
Correction to: Effects of temperature and salinity on the reproductive phases of Macrocystis pyrifera (L.) C. Agardh (Phaeophyceae) in the Magellan region
}

\author{
Juan Pablo Rodríguez ${ }^{1,2}$ (D) $\cdot$ J. Terrados $^{3} \cdot$ S. Rosenfeld ${ }^{1,2} \cdot$ F. Méndez ${ }^{1,2} \cdot$ J. Ojeda ${ }^{1,2,3,4} \cdot$ A. Mansilla $^{1,2}$
}

Published online: 18 March 2019

(C) Springer Nature B.V. 2019

\section{Correction to: Journal of Applied Phycology https://doi.org/10.1007/s10811-018-1693-x}

The original version of this article unfortunately contained mistakes. Please see below necessary corrections:

1) In the Introduction section (2nd page, 3rd paragraph) that refers to the distribution of Macrocystis pyrifera, this should be:

"In Chile, M. pyrifera is distributed from Arica to Cabo de Hornos and the Diego Ramirez Islands (Rozzi et al. 2017)"

$\underline{\text { and not }}$

"In Chile, M. pyrifera is distributed from Valparaiso to Cabo de Hornos and the Diego Ramirez Islands (Rozzi et al. 2017)".

2) In TABLE 1, the value of salinity in summer for Skyring Sound is incorrect. The corrected Table 1 is now shown here:

The online version of the original article can be found at https://oi.org/ 10.1007/s10811-018-1693-x

Juan Pablo Rodríguez

jprp_2@hotmail.cl

1 Laboratorio de Ecosistemas Marinos Antárticos y Subantárticos (LEMAS), Universidad de Magallanes, Punta Arenas, Chile

2 Instituto de Ecología y Biodiversidad (IEB), Santiago, Chile

3 Instituto Mediterráneo de Estudios Avanzados, (IMEDEA, CSIC-UIB), Mallorca, Spain

4 School of Environmental Studies, University of Victoria, Victoria, British Colombia, Canada
Table 1 Measurements of environmental parameters at the time and site of collection of Macrocystis pyrifera

\begin{tabular}{llll}
\hline Locality & Season & Temperature $\left({ }^{\circ} \mathrm{C}\right)$ & Salinity $(\mathrm{psu})$ \\
\hline Skyring Sound & Summer & $9.79 \pm 0.02$ & $22.65 \pm 0.04$ \\
& Winter & $4.71 \pm 0.01$ & $17.32 \pm 0.58$ \\
Otway Sound & Summer & $8.89 \pm 0.08$ & $26.24 \pm 0.05$ \\
& Winter & $5.02 \pm 0.01$ & $30.12 \pm 0.77$ \\
Possession Bay & Summer & $11.32 \pm 0.39$ & $26.92 \pm 0.62$ \\
& Winter & $9.59 \pm 0.01$ & $28.10 \pm 0.52$ \\
Puerto del Hambre & Summer & $9.95 \pm 0.61$ & $33.40 \pm 0.40$ \\
& Winter & $5.70 \pm 0.11$ & $32.41 \pm 0.09$ \\
Paula Bay & Summer & $9.00 \pm 0.40 *$ & $29.10 \pm 3.30 *$ \\
& Winter & $5.70 \pm 0.60 *$ & $31.00 \pm 0.30 *$ \\
\hline
\end{tabular}

\pm 1 standard error $(n=5)$

*Values obtained from Aguirre et al. (2012)

Publisher's note Springer Nature remains neutral with regard to jurisdictional claims in published maps and institutional affiliations. 